\title{
HUBUNGAN PERAWAT DAN PASIEN: IMPLEMENTASI STANDAR KESELAMATAN PASIEN
}

\author{
Rospita A.Siregar ${ }^{1}$
}

\begin{abstract}
The positive impact by implementing a culture of safety within hospital services will increase patient safety, supported by good communication with patients. unexpected events that arise due to the negligence of nurses could cause injury to the patient, such as Near Miss or Adverse Event (Genesis Unexpected). Thus the complaints and litigation is reduced, service quality increases, the image of hospitals and public confidence increased, advised the hospital to have an attitude to support the implementation of the program of patient safety, through training, it is expected to be effected in increasing motivation and work attitudes of nurses in hospitals
\end{abstract}

\section{Keywords: hubungan perawat dan keselamatan pasien}

\section{Pendahuluan}

Definisi dari patient safety atau keselamatan pasien adalah suatu sistem yang dibuat dalam asuhan pasien di rumah sakit, sehingga pasien menjadi lebih aman, bila menjalankan sistem ini dengan benar maka pasien terhindar dari terjadinya cedera yang bisa disebabkan oleh kesalahan akibat melaksanakan suatu tindakan atau tidak mengambil tindakan yang seharusnya diambil. Menurut Institute of Medicine (1999), medical error didefinisikan sebagai: The failure of a planned action to be completed as intended (i.e., error of execusion) or the use of a wrong plan to achieve an aim (i.e., error of planning).Sedangkan menurutThe American Hospital Asosiation (AHA) Board of Trusteesmengartikan bahwa keselamatan dan keamanan pasien (patient safety) merupakan sebuah prioritas strategic yang menetapkancapaian-capaian peningkatan yang terukur untuk medication safety sebagai target utamanya. Tahun 2000, Institute of Medicine, Amerika Serikat dalam "TO ERR IS HUMAN, Building a Safer Health System" melaporkan bahwa dalam pelayanan pasien rawat inap di rumah

\footnotetext{
${ }^{1}$ Dosen Tetap FK-UKI
}

sakit ada sekitar 3-16\% Kejadian Tidak Diharapkan (KTD/Adverse Event). Menindaklanjuti penemuan ini, tahun 2004, WHO mencanangkan World Alliance for Patient Safety, program bersama dengan berbagai negara untuk meningkatkan keselamatan pasien di rumah sakit.

Menurut Depkes (2006) keselamatan pasien di rumah sakit adalah suatu sistem di mana rumah sakit membuat asuhan bagi pasien sehingga pasien merasa lebih aman. Salah satu tujuan penting dari penerapan sistem keselamatan pasien di rumah sakit ada- lah mencegah dan mengurangi terjadinya Incident Keselamatan Pasien (IKP), bahwa dalam pelayanan kesehatan IKP merupakan kejadian atau situasi yang dapat mengakibatkan atau berpotensi mengakibatkan cidera yang seharusnya tidak terjadi. IKP ini meliputi kejadian tidak diharapkan (KTD), kejadian nyaris cidera (KNC), kejadian potensial cidera (KPC), kejadian centinel (KKPRS 2007). Lebih jelas dapat dilihat dalamKepmen nomor 496/Menkes/SK/IV/2005 yang mengatur tentang pedoman audit medis di Rumah Sakit, dimana tujuan utamanya adalah untuk tercapainya pelayanan medis prima di rumah sakit yang jauh dari medical error dan memberikan keselamatan bagi pasien. 
Maka tujuan dilakukannya sistem "Patient safety" adalah: diharapkan tercipta budaya keselamatan pasien di rumah sakit, adanya peningkatan akuntabilitas rumah sakit terhadap pasien dan masyarakat; diharapkan terjadi penurunan Adverse Event atau Kejadian Tidak Diharapkan (KTD) di rumah sakit, Terlaksananya program-program pencegahan sehingga tidak terjadi pengulangan KTD.

\section{Permasalahan}

1. Bagaimana perawatmengimplementasikan sistem keselamatan pasien?

2. Apa saja yang harus diperhatikan oleh perawat dalam mengimplemtasikan sistem keselamatan pasien?

\section{Tujuan Penulisan}

1. Untuk Mengetahui sikap dan perilaku perawat berkaitan dengan implementasi sistem keselamatan pasien

2. Untuk Mengetahui hal apa saya yang harus diperhatikan perawat dalam mengimplementasikan sistem keselamatan pasien

\section{Perawat}

Perawat (bahasa Inggris: nurse, berasal dari bahasa Latin: nutrix yang berarti 'merawat atau memelihara') adalah profesi yang difokuskan pada perawatan individu, keluarga, dan masyarakat sehingga mereka dapat mencapai, mempertahankan, atau memulihkan kesehatan yang optimal dan kualitas hidup dari lahir sampai mati.

Florence Nightingale adalah pelopor perawat modern, penulis dan ahli statistik. Ia dikenal dengan nama Bidadari Berlampu (The Lady with the Lamp) atas jasa-jasanya yang tanpa kenal takut mengumpulkan korban perang pada perang Krimea, di semenanjung Krimea, Rusia.

Perawat bekerja dalam berbagai besar spesialisasi di mana mereka bekerja secara independen dan sebagai bagian dari sebuah tim untuk menilai, merencana- kan, menerapkan dan mengevaluasi perawatan. Ilmu Keperawatan adalah bidang pengetahuan dibentuk berdasarkan kontribusi dari ilmuwan keperawatan melalui peer-review jurnal ilmiah dan praktik yang dibuktikan berbasis. Ini merupakan bidang yang dinamis praktik dan penelitian yang didasarkan dalam budaya kontemporer dan kekhawatiran itu sendiri dengan baik mainstream dan subkultur terpinggirkan dalam rangka untuk memberikan perawatan budaya paling sensitif dan kompeten.

Saat ini profesi perawat telah mendapatkan perlindungan hukum melalui disahkannya UU RI Nomor 38 Tahun 2014 Tentang Keperawatan.Dengan adanya undang undang ini diharapakan perawat dapat bekerja sesuai peran profesinya secara lebih profesional, bertanggungjawab dan lebih optimal.

\section{Tanggung Jawab Hukum Perawat}

Perawat yang bekerja di rumah sakit bekerja penuh dengan mendapat gaji,dalam ilmu hukum dikenal doktrin Vicarius Liability atau respondeat superior atau hubungan majikan dengan buruh.Dalam hal ini rumah sakit disebut majikan. Disamping itu hubungan yang timbul dari tenaga perawatan dan pihak rumah sakit dikuasai juga oleh hukum perburuhan. Dalam praktek juga terdapat tenaga kesehatan tertentu yang tidak mempunyai hubungan perburuhan pada rumah sakit, intinya seorang perawat dengan sifat profesionalismenya bertanggungjawab atas kerugian pasien yang disebabkan kelalaiannya, dengan alasan rumah sakit mempergunakan tenaga perawat kontrak lepas. Selanjutnya apabila di lihat dari hubungan hukum yang timbul antara pasien dan rumah sakit dapat dibedakan pada 2 macam perjanjian, yaitu :

1. Perjanjian perawatan dimana terdapat kesepakatan antara rumah sakit dan pasien bahwa pihak rumah sakit menyediakan kamar perawatan dan dimana tenaga perawat melakukan tindakan perawatan.

2. Perjanjian pelayanan medis di mana terdapat kesepakatan antara rumah sakit dan pasien bahwa tenaga medis pada rumah sakit akan berupaya 
secara maksimal untuk menyembuhkan pasien melalui tindakan medis (inspannings verbintenis).

Untuk menilai sahnya perjanjian tersebut dapat diterapkan Pasal 1320 KUH Perdata, sedangkan untuk pelaksanaan perjanjian itu sendiri harus dilaksanakan dengan itikad baik sesuai denga ketentuan pasal 1338 dan 1339 KUHPerdata. Bertitik tolak dari hal diatas maka hubungan pasien dan tenaga perawat di rumah sakit dapat berupa hubungan hukum pasien dengan dokter, juga hubungan pasien dengan perawat yang berupa kontrak ,dimana tenaga kesehatan harus berupaya memberikan pelayanan sesuai dengan kemampuan dan perangkat ilmu yang dimiliki. Kontrak ini dapat inspanings verbintenis maupun resultaatsverbintenis.Selanjutnya hubungan hukum antara dokter dengan perawat dapat merupakan hubungan rujukan atau delegasi. Pada hubungan rujukan tenaga lain tersebut melakukan tindakan sesuai dengan keputusannya sendiri sedangkan delegasi tenaga kesehatan lain tidak dapat mengambil kebijaksanaan sendiri tapi melakukan tindakan sesuai dengan delegasi yang diberian oleh dokternya, Di suatu rumah sakit para dokter tidak bisa bekerja tanpa bantuan perawat. Sebaliknya perawat bekerja harus berdasarkan instruksi dokter, perawat tidak berwenang untuk menindak secara mandiri, kecuali dalam bidang tertetu yang sifatnya umum dan termasuk asuhan perawat (nursing care). Namun kenyataannya sehari-hari perawat melakukan tindakan yang sebenarnya termasuktugas dokter.Sejak dahulu kala, ada batas yang tidak jelas antara tindakan yang termasuk bidang medis yang harus dilakukan oleh profesi kedokteran dan tindakan yang termasuk wewenang profesi perawat.Terdapat suatu wilayah bidang yang dilakukan oleh para perawat yang sebenarnya termasuk bidang medis. Dilihat dari segi perawatan, tampak ada bidang yang saling tumpang tindih. Dasar hukum pendelegasian ini diberikan dalam suatu arrest hoge raad tanggal 4 November1952 dimana dikatakan bahwa orang yang belum pernah menjadi dokter (dimaksudkan semi arts) dapat melakukan tindakan kedokteran di bawah pengawasan. Ketentuan ini diberlakukan juga pada perawat ini disebut juga perpanjangan lengan dokter atau teori verlengde arm van de arts.

Syarat yang harus dipenuhi untuk delegasi tindakan medis sebagai berikut :

1. Penegakan diagnosis, pemberian atau penentuan terapi serta penentuan indikasi, harus diputuskan dokter itu sendiri, tidak dapat didelegasikan.

2. Delegasi tindakan medis itu hanya dibolehkan jika dokter tersebut sudah sangat yakin bahwa perawat yang menerima delegasi itu sudah mampu untuk melakukannya dengan baik.

3. Pendelegasian itu harus dilakukan secara tertulis termasuk instruksi yang jelas tentang pelaksanaannya bagaimana harus bertindak jika timbul komplikasi dan sebagainya.

4. Harus ada bimbingan atau pengawasan medik pada pelaksanaanya . Pengawasan tersebut tergantung kepada tindakan yang dilakukan, Apakah dokter itu harus berada di tempat itu ataukah ia dapat dipanggil dan dalam waktu singkat berada di tempat.

5. Orang yang didelegasikan itu berhak untuk menolak apabila ia merasa tidak mampu untuk melakukan tindakan medis tersebut (Leenen).

\section{Tindakan Perawat}

Pada tahun 1982 dewan pusat kesehatan masyarakat (central raad voor de volksgezondheid) telah membuat ketentuan mengenai tindakan apa yang boleh dilakukan oleh perawat yaitu :

1. Tindakan dalam rangka penerusan observasi dan bimbingan pasien selama di rumah sakit.

2. Tindakan perawatan dan pengurusan pasien(verpleging en verzorging).

3. Tindakan di bidang medis yang berhubungan denga aktivitas diagnostik dan terapi dari dokter dan yang dilaksanakan atas instruksinya. 


\section{Pasien}

Pasien atau pesakit adalah seseorang yang menerima perawatan medis. [ Sering kali, pasien menderita penyakit atau cedera dan memerlukan bantuan dokter atau perawat untuk memulihkannya. Sedangkan kata pasien berasal dari bahasa Indonesia analog dengan kata patient dari bahasa Inggris yang artinya sabar. Patient diturunkan dari bahasa Latin yaitu patiens yang memiliki kesamaan arti dengan kata kerja pati yang artinya "menderita".

Dalam pelayanan kesehatan/health care terdapat dua kelompok yang perlu di bedakan yaitu :

1. Health Receivers yaitu penerima pelayanankesehatan, yang termasuk kelompok ini : pasien yaitu orang sakit, mereka yang ingin memelihara/ meningkatkan kesehatannya, misalnya ingin di vaksinasi atau wanita hamil yang memeriksakan kandungannya.

2. Health Provider yaitu pemberi pelayanan kesehatan contohnya : medical providers : dr,drg

Tenaga bidang kesehatan lain : apoteker,assisten apoteker, bidan, perawat,analis/laboran, ahli gizi, dan lain-lain

Hubungan antara perawat dan pasien bisa merupakan relasi medis dan juha relasi hukum, dalam hal ini disebut kontrak ( perjanjian ) medis yang bila hanya dalam rangka penyembuhan ( kuratif) disebut kontrak terapeutik. Hukum perikatan menyatakan syaratnya suatu persetujuan dan bila ada yang merasa tidak puas atau menimbulkan kerugian ( menurut KUH Perdata 1365 )

Orang yang bersalah menimbulkan kerugian wajib mengganti kerugian tersebut, kontrak medis bisa tertulis dan bisa pula tidak tertulis dan bila salah satu pihak tidak memenuhi kewajibannya disebut wanprestasi. Untuk meghindari tuntutan atau gugatan hukum maka tenaga medis harus mencatat semua tindakan dalam dokumen pasien yang disebut rekam medis. Pusat dari praktik kedokteran adalah hubungan relasi antara pasien, dan dokter yang dibangun ketika seseorang mencari dokter untuk mengatasi masalah kesehatan yang dideritanya.
Dalam praktik, seorang perawat haru membangun relasi dengan pasien sebagai berikut :

1. mengumpulkan data (riwayat kesehatan, dan pemeriksaan fisik dengan hasil laboratorium atau citra medis)

2. menganalisis data

3. membuat rencana perawatan (tes yang harus dijalani berikutnya, terapi, rujukan)

4. merawat pasien

5. memantau, dan menilai jalannya perawatan, dan dapat mengubah perawatan bila diperlukan.

Semua yang dilakukan perawat harus tercatat dalam sebuah rekam medis, yang merupakan dokumen yang berkedudukan dalam hukum. Perawatberkewajiban memberikan informa si yang cukup kepada pasien memainkan peranan yang penting agar pihak pasien dapat memberikan putusan persetujuan yang tepat dan nyata ( real consent ).karena itu mendapatkan informasi merupakan salah satu hak dari bill of rights terhadap pasien. Sebagaimana diketahui bahwa pada tahun 1992 The American Hospital Association telah menerbitkan bill of rights terhadap pasien, sebagai berikut :

1. Hak atas kepedulian dokter

2. Penghormatan terhadap privacy dari klien

3. Hak atas kerahasiaan informasi

4. Hak untuk mendapatkan informasi yang jelas dan cukup

5. Hak untuk mendapatkan/diperlihatkan rekam medis (medical record)

6. Dan lain-lain.

\section{Hubungan Perawat dan Pasien}

Contoh kasus atas nama Raffles di Rumah Sakit $\mathrm{X}$ ( Jakarta ) umur 1 tahun 6 bulan pada tanggal 11 Juni 2014, pasien di rawat di ruangan Mawar dengan diagnosa kejang demam. Sesuai instruksi dokter yang merawat bahwa diperintahkan agar diberikan obat anti kejang yang bernama Pentoin secara infus, dengan tujuan mencegah kembali pasien kejang. 
Perawat yang baru bertugas tanpa melihat catatan petugas perawat sebelumnya, langsung mencabut infus. Apa yang terjadi ; beberapa menit setelah pencabutan infus pasien mengalami kejang-kejang sampai tidak sadarkan diri.Segera keluarga pasien melaporkan kejadian ini.

Analisa dari kasus di atas: terlihat bahwa kelalaian perawat sangat membahayakan keselamatan pasien. Seharusnya saat pergantian jam dinas semua perawat diwajibkan mengikuti sesi laporan harian yang disampaikan oleh petugas sebelumnya, dengan mengikuti sesi laporan tersebut, petugas yang akan bertugas akan mendapatkan berita tentang kondisi semua pasien yang dirawat dan rencana baru sesuai instruksi kerja yang terakhir diberikan oleh dokter.

Didalam kasus ini perawat juga tidak menjalankan prinsip yang benar dalam pemberian obat. Seharusnya perawat melihat terapi yang akan diberikan kepada pasien sesuai atau tidak dengan order, dalam hal ini perawat tidak menjalankan prinsip itu.Disamping itu terkait dengan hal ini perawat tidak mengaplikasikan konsep patient safety dengan benar, terbukti dari kesalahannya pasien mengalami kejang kembali, tentu hal ini samhat membahayakan, bahkan dengan pasien tidak sadarkan diri sudah terjadi kelainan di jalan nafasnya, atau pasien bisa mengalami kematian secara mendadak.

Perawat dalam memberikan asuhan keperawatan kepada pasien harus menerapkan keselamatan pasien. ${ }^{2}$ Perawat harus melibatkan kognitif, afektif, dan tindakan yang mengutamakan keselamatan pasien. Perawat dalam memberikan asuhan keperawatan harus dengan penuh kepedulian. Persepsi perawat untuk menjaga keselamatan pasien sangat berperan dalam pencegahan, pengendalian dan peningkatan keselamatan pasien ${ }^{2}$.Pemberi layanan kesehatan berkontribusi terhadap terjadinya kesalahan yang mengancam keselamatan pasien, khususnya perawat, pelayanan terlama ( 24 jam secara terus menerus) dan tersering

\footnotetext{
${ }^{2}$ Choo, et. al., Nurse's role in medication safety, Jurnal of Nursing Management, Vol 18/No.5, 2010
}

berinteraksi pada pasien berbagai prosedur dan tindakan keperawatan.Hal ini dapat memberikan peluang yang besar untuk terjadi kesalahan dan keselamatan pasien. Selain itu kelelahan pada perawat merupakan faktor yang berkontribusi terjadinya kesalahan. Karakteristik perawat mempengaruhi pekerjaannya sehari-hari dan berpotensi terhadap kesalahan dalam keselamatan pasien ${ }^{3}$.

Perawat dalam melaksanakan keselamatan pasien dipengaruhi oleh faktor internal dan eksternal.Faktor internal merupakan karakteristik perawat yang bersifat bawaan yang teridentifikasi berupa tingkat kecerdasan, tingkat emosional, dan pengalaman pribadi. Faktor eksternal yang mempengaruhi perilaku perawat adalah lingkungan, seperti pengaruh orang lain yang dianggap penting atau kepemimpinan, budaya dan sistem organisasi. Faktor ini sering menjadi faktor dominan yang mewarnai perilaku seseorang ${ }^{4}$. Faktor eksternal berupa pengaruh orang lain juga dapat menimbulkan persepsi perawat terhadap pelaksanaan keselamatan pasien. Perilaku perawat yang tidak menjaga keselamatan pasien berkontribusi terhadap insiden keselamatan pasien. Perawat yang tidak memiliki kesadaran terhadap situasi yang cepat memburuk gagal mengenali apa yang terjadi dan mengabaikan informasi klinis penting yang terjadi pada pasien dapat mengancam keselamatan pasien ${ }^{5}$. Perilaku yang tidak aman, lupa, kurangnya perhatian, motivasi, kecerobohan dan kelelahan beresiko terjadinya kesalahan selanjutnya.Pengurangan kesalahan dapat dicapai dengan memodifikasi perilaku ${ }^{6}$. Menurut Ananta, kejadian-kejadian yang berkaitan dengan keselamatan pasien semakin marak masukke ranah hukum bahkan sampai ke pangadilan. Kenya-

\footnotetext{
${ }^{3}$ White, N., Understanding the role of non technical skills in pa- tient safety .Nursing Standard, 2012, Vol 26/No 26,

${ }^{4}$ Notoatmojo, S, Promosi Kesehatan dan Ilmu Perilaku, Jakarta, Rhineka Cipta, 2007, hal. 21

${ }^{5}$ Reid, J.,\& Bromiley, M. Clinical human factors: the need to speak up to improve patient safety, Nursing Standard, 2012, Vol 26/No 35

${ }^{6}$ Choo, et all, Nurse's role in medication safety, Jurnal of Nursing Management, 2010, Vol 18/No.5
} 
taan bahwa di rumah sakit terdapat puluhan bahkan ratusan jenis obat, ratusan prosedur, terdapat banyak pasien, banyak profesi yang bekerja serta banyaksistem merupakan potensi yang sangat besar terjadinya kesalahan. Keselamatan pasien merupakan hak pasien yang dijamin dalam UU No. 44 Tahun 2009 tentang Rumah Sakit, untuk itu pihak rumah sakit perlu meminimalkan kesalahan-kesalahan yang mungkin terjadi dalam setiap tindakan yang dilakukan terhadap pasien di rumah sakit. Salah satu upaya meminimalkan kejadian-kejadian tersebut adalah dengan pembentukan Tim Keselamatan Pasien di rumah sakit yang bertugas menganalisis dan mengkaji ke- jadiankejadian yang berhubungan dengan keselama- tan pasien.

Strategi meningkatkan keselamatan pasien oleh Permenkes Tahun 2011 melalui enam sasaran keselamatan pasien rumah sakit meliputi identifikasi pasien dengan tepat, meningkatkan komunikasi yang efektif, meningkatkan keamanan obat perlu diwaspadai, memastikan tepat lokasi, tepat prosedur, tepat pasien operasi, mengurangi resiko infeksi terkait pelayanan kesehatan dan mengurangi risiko jatuh. Joint Commision International (JCI) menetapkan sasaran internasional keselamatan pasien dengan meningkatkan keamanan obat-obatan, memastikan lokasi pembedahan, prosedur yang benar dan pembedahan pada pasien yang benar, memastikan keamanan resiko jatuh pasien.

Sembilan solusi keselamatan Pasien di RS sebagaimana terdapat di dalam WHO Collaborating Centre for Patient Safety, 2 May 2007, yaitu:

1) Perhatikan nama obat, rupa dan ucapan mirip (look-alike, sound-alike medication names)

2) Pastikan identifikasi pasien

3) Komunikasi secara benar saat serah terima pasien

4) Pastikan tindakan yang benar pada sisi tubuh yang benar

5) Kendalikan cairan elektrolit pekat
6) Pastikan akurasi pemberian obat pada pengalihan pelayanan

7) Hindari salah kateter dan salah sambung selang

8) Gunakan alat injeksi sekali pakai

9) Tingkatkan kebersihan tangan untuk pencegahan infeksi nosokomial

Berdasarkan kasus diatas solusi untuk pemecahan masalah mengenai perawat yang tidak mengikuti operan pergantian jam dinas. Perawat harus mengetahui standar keselamatan pasien sesuai dengan uraian DepKes, sebagai berikut:

\section{Standar Keselamatan Pasien RS (KARS - DepKes)}

1. Hak pasien

2. Mendidik pasien dan keluarga

3. Keselamatan pasien dan asuhan berkesinambungan

4. Penggunaan metoda-metoda peningkatan kinerja, untuk melakukan evaluasi dan meningkatkan keselamatan pasien

5. Peran kepemimpinan dalam meningkatkan keselamatan pasien

6. Mendidik staf tentang keselamatan pasien

7. Komunikasi merupakan kunci bagi staf untuk mencapai keselamatan pasien.

Uraian tujuh standar tersebut diatas adalah sebagai berikut:

\section{Standar I. Hak pasien}

Standar: Pasien dan keluarganya mempunyai hak untuk mendapatkan informasi tentang rencana dan hasil pelayanan termasuk kemungkinan terjadinya Kejadian Tidak Diharapkan.

Kriteria: Harus ada dokter penanggung jawab pelayanan, dokter penanggung jawab pelayanan wajib membuat rencana pelayanan, dokter penanggung jawab pelayanan wajib memberikan penjelasan secara jelas dan benar kepada pasien dan keluarganya ten- 
tang rencana dan hasil pelayanan, pengobatan atau prosedur untuk pasien termasuk kemungkinan terjadinya Kejadian Tidak Diharapkan.

\section{Standar II. Mendidik pasien dan keluarga}

Standar: RS harus mendidik pasien dan keluarganya tentang kewajiban dan tanggung jawab pasien dalam asuhan pasien.

Kriteria : Keselamatan dalam pemberian pelayanan dapat ditingkatkan dengan keterlibatan pasien yang merupakan partner dalam proses pelayanan. Karena itu, di RS harus ada sistem dan mekanisme mendidik pasien dan keluarganya tentang kewajiban dan tanggung jawab pasien dalam asuhan pasien. Dengan pendidikan tersebut diharapkan pasien dan keluarga dapat: Memberikan informasi yang be- nar, jelas, lengkap dan jujur, mengetahui kewajiban dan tanggung jawab pasien dan keluarga, menga- jukan pertanyaan-pertanyaan untuk hal yang tidak dimengerti, memahami dan menerima konsekuensi pelayanan, mematuhi instruksi dan menghormati peraturan RS, memperlihatkan sikap menghormati dan tenggang rasa dan emenuhi kewajiban finansial yang disepakati.

\section{Standar III. Keselamatan pasien dan kesinambungan pelayanan.}

Standar : RS menjamin kesinambungan pelayanan dan menjamin koordinasi antar tenaga dan antar unit pelayanan.

Kriteria : Terdapat koordinasi pelayanan secara menyeluruh mulai dari saat pasien masuk, pemeriksaan, diagnosis, perencanaan pelayanan, tindakan pengobatan, rujukan dan saat pasien keluar dari RS, terdapat koordinasi pelayanan yang disesuaikan dengan kebutuhan pasien dan kelayakan sumber daya secara berkesinambungan sehingga pada seluruh tahap pelayanan transisi antar unit pelayanan dapat berjalan baik dan lancar, terdapat koordinasi pelayanan yang mencakup peningkatan komunikasi untuk memfasilitasi dukungan keluarga, pelayanan kepe- rawatan, pelayanan sosial, konsultasi dan rujukan, pelayanan kesehatan primer dan tindak lanjut lainnya, terdapat komunikasi dan transfer informasi antar profesi kesehatan sehingga dapat tercapainya proses koordinasi tanpa hambatan, aman dan efektif.

\section{Standar IV. Penggunaan metode-metode peningkatan kinerja untuk melakukan evaluasi dan program peningkatan}

\section{keselamatan pasien.}

Standar : RS harus mendesain proses baru atau memperbaiki proses yang ada, memonitor dan mengevaluasi kinerja melalui pengumpulan data, menganalisis secara intensif Kejadian Tidak Diharapkan, dan melakukan perubahan untuk meningkatkan kinerja serta keselamatan pasien.

Kriteria : Setiap RS harus melakukan proses perancangan (desain) yang baik, mengacu pada visi, misi, dan tujuan RS, kebutuhan pasien, petugas pelayanan kesehatan, kaidah klinis terkini, praktik bisnis yang sehat, dan faktor-faktor lain yang berpotensi risiko bagi pasien sesuai dengan "Tujuh Langkah Menuju Keselamatan Pasien RS", setiap RS harus melakukan pengumpulan data kinerja yang antara lain terkait dengan: pelaporan insiden, akreditasi, manajemen risiko, utilisasi, mutu pelayanan, keuangan, setiap RS harus melakukan evaluasi intensif terkait dengan semua Kejadian Tidak Diharapkan, dan secara proaktif melakukan evaluasi satu proses kasus risiko tinggi, setiap RS harus menggunakan semua data dan informasi hasil analisis untuk menentukan perubahan sistem yang diperlukan, agar kinerja dan keselamatan pasien terjamin.

\section{Standar V. Peran kepemimpinan dalam meningkatkan keselamatan pasien}

Standar: Pimpinan mendorong dan menjamin implementasi program keselamatan pasien secara terintegrasi dalam organsasi melalui penerapan "Tujuh Langkah Menuju Keselamatan Pasien Rumah sakit”, pimpinan menjamin berlangsungnya program proak- 
tif untuk identifikasi risiko keselamatan pasien dan program menekan atau mengurangi kejadian tidak diharapkan, pimpinan mendorong dan menumbuhkan komunikasi dan oordinasi antar unit dan individu berkaitan dengan pengambilan keputusan tentangkeselamatan pasien, pimpinan mengalokasikan sumber daya yang adekuat untuk mengukur, mengkaji, dan menigkatkan kinerja rumah sait serta meningkatkan keselamatan pasien dan pimpinan mengukur dan mengkaji efektifitas konribusinya dalam meningkatkan kinerja rumah sakit dan keselamatan pasien.

Kriteria: Terdapat tim antar disiplin untuk mengelola program keselamatan pasien, tersedia program proaktif untuk identifikasi risiko keselamatan dan program meminimalkan insiden, yang mencakup jenis-jenis kejadian yang memerlukan perhatian, mulai dari "kejadian nyaris cedera (Near miss) sampai dengan "Kejadian Tidak Diharapkan" (Adverse event), Tersedia mekanisme kerja untuk menjmin bahwa semua komponen dari rumah sakit terintregrasi dan berpatisipasi dalam program keselamatan pasien, tersedia prosedure "cepat tanggap" terhadap insiden, termasuk asuhan kepada pasien yang terkena musibah, membatasi risiko pada orang lain dan penyampaian informasi yang benar dan jelas untuk keperluan analisis.

\section{Standar VI: mencakup keterkaitan jabatan dengan keselamatan pasien secara jelas}

Standar: rumah sakit menyelenggarakan pendidikan dan pelatihan yang berkelanjutan untuk meningkatkan dan memelihara kompetensi staf serta mendukung pendekatan interdisiplin dalam pelayanan pasien.

Kriteria: Setiap rumah sakit harus memiliki program pendidikan, pelatihan dan orientasi bagi staf baru yang memuat topik keselamatan pasien sesuai dengan tugasnya masing-masing, setiap rumah sakit harus megintregasikan topik keselamatan pasien dalam setiap kegiatan in-service training dan membe- ri pedoman yan jelas tentang pelaporan insiden dan setiap rumah sakit harus menyelenggarkan pelatihan tentang kerjasama kelompok (teamwork) guna mendukung pendekatan interdisiplin dan kolaboratif dalam rangka melayani pasien.

\section{Standar VII: Komunikasi merupakan kunci bagi staf untuk mencapai keselamatan pasien}

Standar: Rumah sakit merencanakan dan mendesain proses manajemen informasi keelamatan pasien untuk memenuhi kebutuhan informasi internal dan eksternal, transmisi data dan informasi harus tepat waktu dan akurat.

Kriteria: Perlu disediakan anggaran untuk merencanakan dan mendesain proses manajemen untuk memperoleh data dan informasi tentang hal-hal terkait dengan keselamatan pasien, tesedia mekanisme identifikasi masalah dan kendala komunikasi untuk merevisi manajemen informasi yang ada.

Sesuai dengan defenisi patient safety, menurut Cooper ${ }^{7}$ bahwa "patient safety as the avoidance, prevention, and amelioration of adverse outcomes or injuries stemming from the processes of healthcare." Pengertian ini maksudnya bahwa patient safety merupakan penghindaran, pencegahan, dan perbaikan dari kejadian yang tidak diharapkan atau mengatasi cedera-cedera dari proses pelayanan kesehatan. Jika perawat mengetahui dan mengaplikasikan dengan benar konsep patient safety, perawat akan sebisa mungkin meminimalisir kesalahan atau mencegah terjadinya kejadian yang tidak diharapkan.

Perawat seharusnya menerapkan prinsip 6 benar dalam pemberian obat, sebagai berikut :

1. Tepat Obat : mengecek program terapi pengobatan dari dokter, menanyakan ada tidaknya alergi obat, menanyakan keluhan pasien sebelum dan setelah memberikan obat, mengecek label obat, mengetahui reaksi obat, mengetahui efek sam-

\footnotetext{
${ }^{7}$ Cooper et al ,Handbook of research on patient safety and quality care through health informatics, AHISA book series, Hershey PA USA,2014, chapter 5, page 48-75
} 
ping obat, hanya memberikan obat yang didiapkan diri sendiri.

2. Tepat dosis : mengecek program terapi pengobatan dari dokter, mengecek hasil hitungan dosis dengan perawat lain, mencampur/mengoplos obat.

3. Tepat waktu : mengecek program terapi pengobatan dari dokter, mengecek tanggal kadarluarsa obat, memberikan obat dalam rentang 30 menit.

4. Tepat pasien : mengecek program terapi pengobatan dari dokter, memanggil nama pasien yang akan diberikan obat, mengecek identitas pasien pada papan/kardeks di tempat tidur pasien.

5. Tepat cara pemberian : mengecek program terapi pengobatan dari dokter, mengecek cara pemberian pada label/kemasan obat.

6. Tepat dokumentasi : mengecek program terapi pengobatan dari dokter, mencatat nama pasien, nama obat, dosis, cara, dan waktu pemberian obat (Kozier, B. Erb, G. \& Blais, K. (1997) ${ }^{8}$.

Sebagai seorang kepala ruangan hal yang harus dilakukan dalam pemecahan masalah ini adalah menegur perawat yang bersangkutan terhadap kelalaian tindakan yang dilakukan. Selalu mengobservasi berjalannya operan pergantian jam dinas dilaksananakan dengan tepat agar tidak terjadi kesalahan lagi.

Sebagai seorang kepala ruangan menjelaskan kepada keluarga tindakan yang akan dilakukan yaitu pemberian peritoin untuk mengatasi kejang.

\section{Standar Operational Prosedur Penanganan Kejang}

- Definisi : tindakan untuk mengatasi kejang.

- Tujuan: agar demam kejang teratasi atau agar tidak terjadi kejang berulang

- Petugas : Perawat

- Pelaksanaan: Pasang klem infus dan pasang ujung slang infus pada ujung wing needle

\footnotetext{
${ }^{8}$ Kozier, B. Erb, G. \& Blais, K. 1997,Professional Nursing prac- tice: Concepts perspectives,3rd Ed,New York, Addison - Awes- ley USA
}

- Mengatur tetesan cairan : BB $10 \mathrm{~kg}$ pertama $4 \mathrm{ml} / \mathrm{kgBB} / \mathrm{jam}$ lalu BB $10 \mathrm{~kg}$ kedua $2 \mathrm{ml} / \mathrm{kgBB} /$ jam, dan

BB $10 \mathrm{~kg}$ selanjutnya $1 \mathrm{ml} / \mathrm{kgBB} / \mathrm{jam}$

Misalnya berat badan $15 \mathrm{~kg}$ maka kebutuhan cairan rumatan adalah $(10 \times 4)+(5 \times 2)=40+10=50$ $\mathrm{ml} /$ jam, Phenitoin Injeksi : 5 Ampul

Apabila kejang teratasi maka dilanjutkan pemberian fenobarbital secara IV langsung setelah kejang berhenti dengan dosis awal : usia > 1 tahun : 75 mg lalu dilanjutkan dengan dosis rumatan diberikan 4 jam kemudian :dua hari pertama $8-10 \mathrm{mg} / \mathrm{kgBB} /$ hari dibagi dalam 2 dosis dan hari berikutnya $4-5 \mathrm{mg}$ / $\mathrm{kg} \mathrm{BB} /$ hari dibagi dalam 2 dosis.

\section{KESIMPULAN}

1. Keselamatan pasien merupakan hak pasien yang dijamin dalam UU RI No. 44 Tahun 2009 tentang Rumah Sakit

2. Kesalahan yang terjadi dalam proses asuhan medis mengakibatkan cedera pada pasien, bisa berupa Near Miss atau Adverse Event atau Kejadian Tidak Diharapkan.

\section{SARAN}

1. Tenaga keperawatan dalam menjalankan pekerjaannya harus menerapan sistem patient safety .

2. Perlu merapkan standar prosedur operasional dalam pelayanan secara umum maupun secara khusus.

\section{DAFTAR PUSTAKA}

\section{Buku}

Choo et all, Nurse's role in medication safety, Jurnal of Nursing Management, 2010, vol 18/No.5

Cooper et al, Handbook of research on patient safety and quality care through health informatics, AHISA book series, 2014, Hershey PA USA, chapter 5 
Notoatmojo, S, Promosi Kesehatan dan Ilmu Perila- ku, Jakarta: Rhineka Cipta, 2007

Panduan Nasional Keselamatan Pasien Rumah Sakit (Patient Safety). 2005

Reid, J.,\& Bromiley,M. Clinical human factors: the need to speak up to improve patient safety, Nur- sing Standard, 2012, Vol 26/No 35

Tim Keselamatan Pasien RS RSUD Panembahan Se- nopati. Patient Safety. White, N., Understanding the role of non technical skills in patient safety .Nursing Standard, 2012, Vol 26/No 26

\section{Perundang-undangan}

Undang-Undang RI Nomor 38 Tahun 2014 Tentang Keperawatan 